\title{
NEW OF PHILORHIZUS MELANOCEPHALUS (DEJEAN, 1825) (COLEOPTERA: CARABIDAE) NW POLAND
}

\begin{abstract}
New distributional data concerning rare species Philorhizus melanocephalus are provided. specimens caught in NW Poland in 1996-2012 in 6 new localities. Probably Vistula river valley is a north-east border of main distribution area.

Keywords: Philorhizus melanocephalus, rare species, new records, NW Poland

\section{Introduction}

Philorhizus melanocephalus (Dej.) belongs to the carabid family (Carabidae Latr.) and within it to the subfamily Harpalinae Bon., the tribe Lebiini Bon. and the subtribe Dromiina Bon. (Stachowiak 2008). It is distinguished from the other representatives of the family in Polish fauna (Ph. quadrisignatus (Dej.), Ph. sigma (Rossi) and Ph. notatus (Steph.)) by its lack of dark marks on the elytra.

* Department of Invertebrate Zoology \& Limnology, University of Szczecin, Wąska 13, 71-415 Szczecin, Poland, e-mail: ukaszbaran84@gmail.com

** University of Technology and Natural Sciences the Cathedral of Ecoengineering \& Physicochemistry, Sucha 9, 85-796 Bydgoszcz, Poland, e-mail: pogonus@utp.edu.pl
\end{abstract}


The area occupied by the species includes the Mediterranean region, the Near East and the Caucasus, as far as Azerbaijan to the east, and western and central Europe, up to and including the southern part of Scandinavia to the north (Kabak 2003).

In Poland, as in the rest of central Europe, Ph. melanocephalus is a very seldom encountered species and had not been recorded for nearly 40 years. It had previously been observed on the Baltic Coast, in the Pomeranian Lake District, in the Wielkopolsko-Kujawska Lowland, in Lower Silesia, in the Świętokrzyskie Mountains and in the Roztocze region (Burakowski et al. 1974; http://dbtest.biomap.pl 2015). The available information indicates that it is not found beyond the Vistula River valley to the east, which confirms the opinion of Silfverberg (2004), who removed it from the list of species recorded in Estonia (Haberman 1952).

In light of the few records of the species in Poland, which date back many years, we present information confirming its presence in the fauna of Poland, including several new sites on the Baltic Coast and in the Pomeranian Lake District.

\section{Material examined}

\section{The Baltic Coast}

- Hel (N 54.6180 E 18.8102), UTM: CF55; 19.06.1996, 1 ô, macropterous, leg. M. Stachowiak; psammophilic vegetation,

- Dębki (N 54.8324 E 18.1024), UTM: CF18; 3.06.2001, 2 exx. (1 $ð$ and 1 ㅇ), leg. A. Król, macropterous, in a depression between dunes,

- Darłówko (N 54.4102 E 16.3460), UTM: WA83; 21.06.1998, 1 đ̊, macropterous, leg. R. Morawiec,

- Wisełka (N 53.9834 E 14.5811), UTM: VV78; 23.05.1994, 1 q , macropterous, leg. M. Stachowiak.

\section{Pomeranian Lake District}

- Łówcz Górny (N 54.51667 E 17.97389), UTM: XA94; 14.05.2012, 1 q, macropterous, leg. Ł. Baran; fertile beech forest, caught in a Barber trap with ethylene glycol solution, 
- Przytarnia ad Wiele (N 53.9406 E 17.8734), UTM: XV88; 18.05.2001, 1 , macropterous, leg. P. Janicki, psammophilic vegetation at the edge of a young pine forest.

\section{Remarks}

The observations made by the second author indicate that Ph. melanocephalus is a species that prefers open, dry habitats with a mineral substrate - coastal dunes and psammophilic vegetation. It is less often encountered in shaded places and on the edges of moist areas, including peat bogs. Lindroth (1949) classifies it as mesoxerophilous, while according to Müller-Motzfeld (1983) it is characteristic of coastal dunes. In Great Britain it has mostly been found in dry meadows, moors, dunes, sandpits and gravel pits (Luff et al. 1992), but also in urbanized areas (Mabbott 2000). It was recorded by Kielhorn (2005) in ruderal habitats in Berlin.

These beetles are presumably so rarely caught because $P h$. melanocephalus leads a secretive life among grasses and other herbaceous plants or under patches of moss, fallen leaves and plant residue. They rarely fall into traps and when they do are able to escape them if they are not filled with a preservative solution. The delicate body structure of $P h$. melanocephalus is also not conducive to catching them in traps; beetles that have been caught generally decompose very rapidly, even in preservative solution.

\section{References}

Burakowski B., Mroczkowski M., Stefańska J. 1974. Chrząszcze - Coleoptera, Biegaczowate - Carabidae, cz. 2, Katalog fauny Polski, cz. XXIII, t. 3, PWN, Warszawa, 430 p. + map.

Haberman H. 1952. Eesti NSV mardikaliste (Coleoptera) süstemaatiline nimestik leviku ja leiukohtade andmetega. I Röövmardikalised (Adephaga). Loodusuurijate selts Eesti NSV teaduste Akadeemia Juures abiks loodusevaatlejale nr. 8. Tartu. $61 \mathrm{~s}$.

http://dbtest.biomap.pl/pl/db/taxon/perspective/taxon/slug/species-philorhizus_melanocephalus/tr/y/view/default/display_login/n.

Kabak I. 2003. Tribe Lebiini Bonelli, 1810. In: Catalogue of Palaearctic Coleoptera. I. Löbl, A. Smetana (ed.). Vol. 1. Apollo Books, Stenstrup, pp. 408-439. 
Kielhorn K.H.2005. RoteListeund Gesamtartenliste derLaufkäfer(Coleoptera:Carabidae) von Berlin. In: Der Landesbeauftragte für Naturschutz und Landschaftspflege / Senatsverwaltung für Stadtentwicklung: Rote Listen der gefährdeten Pflanzen und Tiere von Berlin. CD-ROM.

Lindroth C.H. 1949. Die fennoskandichen Carabidae. Eine tiergeographisce Studie. 3. Allgemeiner Teil. Zuglelh eine biogeographische Prinzipdiskussion. Goteborgs Kungl. Vetenskaps- och Vitterhets-Samhälles, Slätte Följden, 4 (3): 911.

Luff M.L., Eyre M.D., Rushton S.P. 1992. Classification and prediction of grassland habitats using ground beetles (Coleoptera, Carabidae). Journal of Environmental Management, 35 (4): 301-314.

Mabbott P. 2000. Coleoptera: Carabidae in the London area with a preliminary list of the ground beetles. London Naturalist, 79: 165-176.

Müller-Motzfeld G. 1983. Kritische Liste der Laufkäfer der Bezirke Rostock, Schwerin und Neubrandenburg (Col. Carab.). Natur und Naturschutz Mecklenburg, 19: 5-48.

Silfverberg H. 2004. Enumeratio nova Coleopterorum Fennoscandiae, Daniae et Baltiae. Sahlbergia, 9: 1-111.

Stachowiak M. 2008. Przegląd systematyczny biegaczowatych Polski (Coleoptera, Carabidae) - wersja skrócona, www.entomo.pl.

\section{NOWE INFORMACJE O WYSTĘPOWANIU PHILORHIZUS \\ MELANOCEPHALUS (DEJEAN, 1825) (COLEOPTERA: CARABIDAE) \\ W PÓLNOCNO-ZACHODNIEJ POLSCE}

\section{Streszczenie}

Przedstawiono nowe dane o występowaniu rzadkiego gatunku Philorhizus melanocephalus (Carabidae) w północno-zachodniej Polsce. Kilka okazów w 6 miejscowościach złowiono w latach 1996-2012. Prawdopodobnie dolina Wisły jest północno-wschodnią granicą jego zasięgu.

Słowa kluczowe: Philorhizus melanocephalus, rzadki gatunek, nowe dane, północno-zachodnia Polska

Cite this article as: Baran Ł., Stachowiak M. 2015. New of Philorhizus Melanocephalus (Dejean, 1825) (Coleoptera: Carabidae) NW Poland. Acta Biologica, 22: 133-136. 